\title{
МАКАР ПЕТРОВИЧ ЧЕРЕНЬКО: КАМЕРТОНЫ ПРИЗВАНИЯ
}

\section{К 90-летию со дня рождения выдающегося украинского хирурга и ученого}

«Но ты мне шепнул, вестовой, неспроста...»В этой строфе поэта из стихотворения «Метель» как бы прочерчены незримым пунктиром вехи предназначения личности. Конечно же, каждую нашу большую дорогу во многом предопределяют обстоятельства и время. И все же камертоны судьбы и призвания, эти решающие их предвестники, в таком движении к жизненным вершинам всегда глубоко индивидуальны. Успех приходит лишь к самым упорным и неповторимым, непоколебимым и храбрым.

Осмысливая в новом ключе, в светильниках второго десятилетия XXI века, творческий путь одаренного ученого и хирурга, воспитанника Киевского медицинского института, мужественного солдата минувшей войны Макара Петровича Черенько, вдруг с полной отчетливостью осознаешь, что это были порывы и прорывы сквозь суровые метели бытия. И грани его профессиональных воплощений, в форматах доктора медицинских наук (1968), профессора (1971-1980), а затем заведующего кафедрой общей хирургии в альма-матер (1980-1982), с последующим переходом в статус заведующего кафедрой хирургии педиатрического (1982-1984) и на заключительном этапе исканий и свершений в качестве заведующего, профессора кафедры (до 2002 года) в структуре стоматологического факультета, обозначают дорогу стоика. Это и ступени, но одновременно и вечные знаки единоборств на таких драматичных вертикалях жизни.

Итак, вернемся в юность нашего персонажа. Сороковые-роковые, грозные года пронесшегося так недавно века - лишь грозная прелюдия самых тяжелых битв летописи Второй мировой войны. Юношам, родившимся на переломе 20-х годов, в эти дни исполнялось 18 и перед ними неотвратимо вставали огневые испытания. Так произошло и с Макаром Черенько, пришедшим в мир 26 августа 1925 года. Началась его солдатская илиада в ипостаси командира артиллерийского расчета. Его, по нынешним параметрам, не очень мощная пушка с диаметром ствола 45 мм входила в те годы в спасительный противотанковый арсенал. Вот из этого орудия молодому солдату с Черниговщины в одном из тяжелейших боев удалось уничтожить вражеский танк. Трудно представить эти минуты... Его

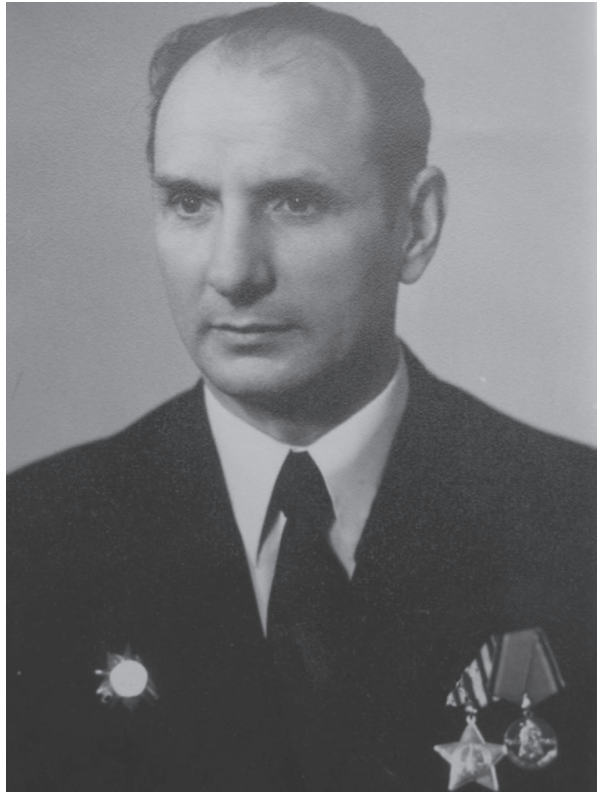

подвиг был отмечен орденом Славы III степени. Второй, самый почетный, солдатский орден Славы II степени Черенько получил за успешное отражение другой танковой атаки новейшими броневыми машинами вермахта. Был отмечен и орденами Отечественной войны II и III степени.

До конца войны было еще не близко, и в один из дней на передовой Черенько получил тяжелое ранение в легкое. Более года, преодолевая септическое состояние, он пребывал на лечении в госпитале в Чернигове. Это были его родные края, и неутомимо и настойчиво, почти каждый день его тихая и набожная мама Федора Митрофановна, преодолевая в оба конца дорогу около 100 километров, старалась всячески поддержать сына хотя бы небольшими передачами. Судьбу решило прибытие в госпиталь торакального хирурга. Как раз ему, при непосредственном вмешательстве на легком, удается удалить осколок, вызвавший внутригрудной абсцесс. По сути, смелая радикальная операция в руках умельца как бы предшествовала амосовским торакальным штурмам. Так Макар Черенько фактически обрел «второе дыхание».

Умение его спасителя и предрешило им выбор медицины как дальнейшей своей жизненной парадигмы. Макар Петрович, практически сразу после излечения, поступает в Киевский медицинский 
институт. Идет голодный 46-й, и вместе с тем, хирургия в стенах прославленного вуза находится на своем пике развития. Как раз в данный период здесь трудятся корифеи хирургии профессора А.П. Крымов, И.Н. Ищенко, М.И. Коломийченко, Д.М. Городинский, А.Г. Елецкий, плеяда их видных коллег. Вскоре в эти ряды вливается Н.М. Амосов. Со студенческих лет Черенько прикипает к хирургии, и к получению врачебного диплома в 1952 году он уже самодостаточная фигура в сложной профессии.

Но что такое, на самом деле, подобный жребий? О таком, всякий раз новом штурме, пожалуй, неотразимо точно сказано Ремарком в «Триумфальной арке» глазами ее героя-врача: «разве понять эту бездыханность, это напряжение. Когда вот-вот сделает первый разрез, когда вслед за легким нажимом тянется узкая полоска крови и, подобно занавеси, открывается то, что никогда не видело света, когда, подобно охотнику в джунглях, ты идешь по следу и вдруг, в разрушенных тканях, опухолях, узлах и разрывах лицом к лицу сталкиваешься с могучим соперником - смертью и вступаешь в борьбу, вооруженный лишь иглой, лезвием и бесконечно уверенной рукой...».

Так шел вперед и Макар Черенько. Разумеется, это словно прочная основа всего дальнейшего серьезная школа общей и гнойной хирургии, однако влекомым полем для недавнего воина становится поприще эндокринной хирургии в своей глобальной в те давнишние времена сосредоточенности на хирургических проблемах при заболеваниях щитовидной железы, равно как и надпочечников. Его учителями и примером становится талантливый эндокринный хирург, выполнивший более 4 тыс. операций на таинственном островке жизнедеятельности - профессор Александр Кириллович Горчаков (1900-1960). Именно Горчаков, разрабатывая свои оперативные варианты, делает, в частности, более эффективной и безопасной субтотальную струмэктомию как альтернативу спасения при раке и других серьезных поражениях органа. Эти восемь лет, выпавшие на дистанции работы рядом и вместе с А.К. Горчаковым, становятся для Макара Петровича как бы его важным фундаментом в данной сфере. И вместе с тем, яркая черта, присущая волонтеру в этой особой отрасли - учиться повсюду. Очень многое ему дает совершенствование в Москве, под руководством блестящего специалиста в области эндокринной хирургии профессора Олега Владимировича Николаева. Свои изюминки Черенько воспринимает и вырабатыва- ет, наблюдая за операциями и стилем Михаила Исидоровича Коломийченка. А когда в Киеве достигает расцвета Институт клинической и экспериментальной хирургии под руководством Александра Алексеевича Шалимова, Черенько, уже будучи профессором, осваивает здесь методики селективной ваготомии. В своем марафоне в составе кафедры хирургии стоматологического факультета Макару Петровичу довелось трудиться рядом и вместе с такими величинами хирургии, как Дмитрий Федорович Скрипниченко и Василий Дмитриевич Братусь. Яркие и поучительные страницы.

«С кем протекли его боренья? С самим собой, с самим собой...» - так можно сказать о Макаре Петровиче как хирурге-подвижнике. 15 лет разносторонних рисков и решений над операционным столом, сперва и преимущественно на Подоле, где Макар Петрович плодотворно сотрудничает с В.Д. Братусем и фактически руководит кафедрой, «прикрывая тыл» министра здравоохранения УССР, становясь впоследствии его преемником. Потом будут хирургические дни и ночи в не менее славной больнице № 23, другом крупном многопрофильном клиническом форпосте столицы. Тут, в этих стенах судьба соединяет Макара Петровича с иными подвижниками избранного дела - профессорами Валентиной Сергеевной Рогачевой и Петром Дмитриевичем Фоминым. В 1968 году Черенько защищает докторскую диссертацию по оригинальному и важному разделу современной оперативной эндокринологии «Функциональное состояние и реактивность нервной и сердечнососудистой систем у больных диффузным токсическим зобом до операции и в отдаленные сроки после нее». Судьба больного как своя... Смысл диссертации как раз говорит об этом. Первым в Советском Союзе Черенько использует радиоактивный йод как спасительный щит при токсическом зобе. Стремясь оперировать максимально щадяще, врачэнтузиаст впервые разрабатывает и способ профилактики послеоперационного гипопаратиреоза путем прижизненного окрашивания прищитовидных желез толуидиновым синим. Выходят в свет, в числе других 200 публикаций, его монографические труды «Осложнения при операциях на щитовидной железе» (1977), «Заболевания эндокринных желез» (1978), «Заболевания и повреждения шеи» (1984), «Брюшные грыжи» (1995) в соавторстве. В 1999 году издается первый национальный украинский учебник «Загальна хірургія з анестезіологією. Основи реаніматології та догляду за хворими». Второе издание основательного ученого пособия 
будет осуществлено в 2004 году, и автор, увы, уже не увидит его. Символом признания становится и присуждение в 1988 году Государственной премии Украины в области науки и техники группе специалистов, в том числе М.П. Черенько, за принципиальные нововведения в эндокринной хирургии. Примечательно, что по инициативе ученика и последователя, пусть и посмертно, в группу лауреатов включен и его учитель А.К. Горчаков. При этом можно также отметить, что Макар Петрович был универсальным хирургом, каких сейчас практически нет. Он оперировал на органах грудной полости, владел арсеналом всех операций на органах брюшной полости и передней брюшной стенки, выполнял гинекологические операции, неотложные нейрохирургические вмешательства (трепанации черепа), имел большой опыт в гнойной хирургии, выполнял сосудистые операции и даже сделал несколько операций на сердце.

В связи с универсальностью и богатым опытом клинициста имел собственную точку зрения, в определенном смысле смелость ее отстаивать. Можно привести интересный факт, когда на заседании общества хирургов Киева и области Макар Петрович настаивал на тактике преимущественно консервативного лечения острого панкреатита в первые недели заболевания вопреки доминирующей и насаждаемой тогда представителями школы Шалимова тактике ургентного хирургического лечения. Именно отстаиваемая Макаром Петровичем тактика подтвердилась в дальнейшем и оказалась общепринятой в современной хирургии.

Отметим, что Макар Петрович подготовил 12 докторов и кандидатов наук, не считая неисчислимого отряда иных учеников и воспитанников, которые с изумлением и наслаждением высокой техничностью вглядывались в его виртуозные хирургические вмешательства, особенно на щитовидной железе, в стиль общения с пациентами, в безошибочный опыт диагноста, клинициста, но и настоящего утешителя пациентов.

Конечно же, Макар Петрович, как и три его брата, обладал большими врожденными способностями, удивительным образом доказав, что истинным интеллигентом, личностью чеховского образца можно стать и в первом поколении. Один из них стал директором школы, Героем Социалистического Труда, фактически вторым Сухомлинским.

С молодости доктор тянулся к музыке и живописи, был поклонником и неизменным посетителем оперного театра, хотя сам играть не научился - эту эстафету сердца в тяжении к музыке восприняли и понесли его сын и дочь, а также внуки, понятно, лишь как любители. Казалось бы, если исключить душевные страдания (мучительная болезнь и смерть жены, земного «ангела-хранителя») и тяжелейшие личные послеоперационные тяготы, выпавшие на долю Черенько, перед нами предстает некое, достаточно оптимальное хирургическое и научное поле. С вполне благополучными контурами честной бескорыстной судьбы. Но на самом деле, так или не так, неведомые светотени отчетливо встают в разговоре с Сергеем Макаровичем Черенько, ныне видным хирургом-эндокринологом, профессором и руководителем отдела в составе Научно-практического центра эндокринной хирургии. «Отец, - задумчиво говорит мой собеседник, - явственно ощущал необходимость личного восприятия хирургических инноваций в современном мире. Он был хирургом-искателем, страстным и совестливым. Но за рубежом ему удалось побывать лишь как туристу. Ведь трудился Макар Петрович в условиях «железного занавеса». Однажды его пригласил в Болгарию хирург Зографски, его ученик. Поездка представлялась и профессионально важной. И вот отцу, кавалеру двух орденов Славы и двух орденов ВОВ, без объяснения причин вдруг отказали в визе».

- Но сфера его основного призвания бурно развивалась, в обиход входили операции с учетом европейского опыта, как это произошло и с Вами. Как складывались отцовские видения новизны и их оценка?

- Придя в ту же профессию, я и впрямь оперировал несколько иначе, чем в образцах классических схем. Сказались, в частности, по инициативе и предложению Европейской ассоциации хирургов, мои стажировки в ряде западных клиник. Однажды, на пороге 2000-х, пригласил отца в нашу клинику. Он, по скромности, отказался, попросив, однако, привезти кассету с записью операций. Всматривался в малоинвазивные новшества с упоением и радостью.

- К детям своим папа, как и мама, врачстоматолог, также опытный и скромный, проявляли неиссякаемую заботу, сочетая ее с достаточной выдержкой, - продолжает Татьяна Макаровна Черенько - профессор-невролог в составе школы Н.Б. Маньковского и С.М. Винничука, доктор медицинских наук. Особенной папиной нежностью (с заметными всем элементами идеализации) была окружена я. Когда, избрав вдруг нейроиммунологию, я на 10 лет ушла из клиники, отец этот поворотный шаг, со стороны непонятный, одо- 


\section{ІСТОРІЯ ЕНДОКРИНОЛОГІї}

брил. Предоставлял мне и Сергею всегда свободный выбор.

70 лет Победы и... Макар Петрович, смотрящий на нас своим добрым взглядом труженика и мудреца с немногих фотографий, по возрасту мог бы быть участником великого апофеоза. Как, к примеру, его коллега-фронтовик видный травматолог профессор Евгений Тимофеевич Скляренко, шагнувший в десятый свой перечень десятилетий. Что ж, у каждого свой сценарий и своя звезда. И этот свет уже далекой звезды Макара Черенько продолжает сиять в его школе, его учениках, родных. В таком легендарном смысле герой-рыцарь войны и мира с нами.

Разумеется, архитектоника этого очерка, к слову, вызванного к жизни и нежной памятью о Макаре Петровиче его сына, дочери и внуков, отражает лишь отдельные вехи на неповторимом пути личности, о которой можно сказать: «И лик его Всевышний зрит». Но любовь друг к другу в наши дни дороже всех наград. «Чтобы знали, чтобы знали» этот завет Михаила Булгакова касается каждого в земном мире, в этом коротком данном нам промежутке. В этом смысле я испытываю моральное удовлетворение. Что мне было доверено еще раз попытаться воссоздать черты самоотверженного хирурга, остававшегося у операционного стола, если вдуматься, таким же рядовым долга, как и в далекие дни солдатской судьбы. И в этом также заключено особое очарование профессора Макара Черенько.

Ю. Виленский 